\title{
PROBLEMS IN MULTICULTURAL SOCIETY: FROM LANGUAGE POLITENESS TO HATE SPEECH
}

\author{
${ }^{1 *}$ Rahmadsyah Rangkuti and ${ }^{2}$ Andi Pratama Lubis \\ ${ }^{1}$ Department of English, University of Sumatera Utara, Medan, Indonesia \\ ${ }^{2}$ Departemnt of Arabic, University of Sumatera Utara, Medan, Indonesia \\ *Corresponding author: rangkuti@usu.ac.id
}

\begin{abstract}
Indonesia is known as a nation that has many privileges such as cultural diversity and local wisdom. Cultural diversity that includes ethnic, linguistic and religious diversity is a gift and grace from God Almighty that must be managed and well maintained by all elements of the nation. Caring for diversity and harmonization in multicultural society in the era of information technology or globalization is the biggest challenge of the day. The goal is to maintain harmony and unity in the midst of a multicultural society. In such conditions the ability and understanding of the language politeness play an important role in maintaining the harmonization of multicultural society. Based on that, this article aims to reveal that the problems that can threaten the unity and integrity of this republic are not only derived from differences of certain political and ideological attitudes, but may also originate and begin from languages impoliteness to hate speech. Applying language politeness theory proposed by Pranowo (2009) which extracted values embedded the local wisdom of the Indonesian is considered capable in anticipating hate speech actions. Thus harmonization in multicultural society in Indonesia can be well maintained.
\end{abstract}

Keywords: multicultural society, language politeness, hate speech, cultural diversity, local wisdom

\section{Introduction}

The diversity of ethnic, language, and religion in Indonesia is the grace from The One Almighty God. Based on this reality, Indonesia is known as one of multicultural countries. In terms of socio-history and politics of inevitability, the multiculturalism is written in the 1945 Constitution of the Republic of Indonesia. The inevitability of pluralism of Indonesia became the foundation of spirit of harmony by upholding the motto Bhineka Tunggal Ika which is easy to say but difficult to put in action. It is the expression that people still need to fight for and preserve. It is also the expression that is lately being the center of attention of all elements in this nation after the incident of blasphemy against religion committed by the former governor of DKI Jakarta Basuki Tjahaya Purnama a year ago in Kepulauan Seribu. 
After that incident, the issue of diversity which is the characteristic of multicultural society resurfaced in people's mind as if they were awakened from their long sleep. After the Reformation twenty years ago, this nation is again left astounded by the issue of anti-diversity that could threaten the unity of Republic of Indonesia.

It is classic case that this issue is framed as the result of the differences in certain politics and ideology. Government officials argue that "the uproar" happened from the last year is due to the political-ideological interest of some groups (refer to Purnomo, 2017: 127). This is a problem of multicultural life in a developing democratic country.

\section{Literature Review}

The question now is if the diversity problem faced by this nation purely arises from the differences of practical politics and ideology. Has not this nation been long established on the foundation of diversity even long before this nation was freed from colonialism? The next question is why the issue of diversity only busted out and has been exaggerated after Basuki Tjahaya Purnama committed blasphemy and then Muslims took some actions to defend their religion. Did not "the uproar" in this nation start from the language impoliteness and hate speech?

This uproar also worsens the complexity of the nation's character degradation that is known for that nation of politeness. In fact, it should be said that the phenomenon of the use of language in political realm tend to be the means of language impoliteness and hate speech (refer to Pranowo, 2009; Chaer, 2010; Sosiowati, 2013; Muhadjir, 2016; SE Kapolri No. 6 Tahun 2015). Based on this phenomenon, this article discusses about language politeness, hate speech and their relation with the direction that the multicultural people of Indonesia will head in the future.

Language is the reflection of its user. In other words, language reflects the personality of a person. Language is also the reflection of personality of a nation's culture. Experts stated that language has various function including transactional and interactional function (refer to Siregar, 2011: 137). According to Siregar, transactional function is the function of language to express message which covers the disclosure of ideas, thought, feeling, desire, attitude, and factual information. Meanwhile, interactional function of a language is the use of language to create and maintain a certain social relationship which aims to establish interpersonal relationship both in the context of intra-group and inter-groups in a certain society.

In daily life, people use language to do something or to influence others to do something (compare to, Tarigan, 1990:145; Griffiths, 2006: 148; Brasdefer, 2014: $323 ;$ ). In the context of social life that upholds diversity, the use of language always aims to keep social relationship to have more harmony, peace, and tolerance. This statement is in line with Sibarani (2001: 17) who said that language politeness can show that one has good attitude. Besides, language politeness is contextual and always bipolar. Therefore, the purpose of one having polite language is to smoothen and harmonize communication so that a message is not only understood by the 
participant of communication, but also liked and followed in line with what the speaker intends to.

A bit different from the expert above, Pranowo (2009:15) mentioned that language politeness is the manifestation of self actualization. According to him, language politeness is not only to reach harmony in a communication, but also to generate effect for harmonious communication. For him, everyone should maintain their own dignity so that others will also respect it. This is what he called the essence of language politeness.

Not so different from what has been explained by the experts above, Leech (2014:3) stated that language politeness is a form of communicative behavior influenced by socio-cultural factor in a certain society. According to Leech, language politeness is when the speaker in his speech gives favor/benefit not only to himself but also the hearer and the third party whether the third party is present or not in the speech situation.

Based on the experts above, language politeness is a good and wise attitude in using language which is designed to build harmonious interpersonal and inter-groups relationship.

\section{Discussion}

If only the leaders and politicians in this nation could give example of language politeness and did not generate hate speech in their speech then this nation would not experience socio-political uproar. They should have been aware that a polite language is a powerful weapon to influence others. Using polite language can please others. On the contrary, language impoliteness can cause horizontal and vertical conflict.

Language impoliteness could also reflect violence. Not physical violence but verbal violence which tends to represent authority (read, Baryadi, 2012). According to Pranowo (2009: 10), a person having impolite behavior is always due to several factors, they are (1) always driven by emotion in his speech, (2) always wants to corner the hearer in his every speech, (3) always has prejudice toward the hearer and, (4) always protective of his opinion.

All the language impoliteness factors explained by Pranowo above can be said as the root of hate speech. It is a language phenomenon that gains many people attention. Referring to circular Kapolri Nomor: SE/6/X/2015 regarding hate speech, what is called hate speech is all acts considered as insulting, defamation of name, blasphemy, unpleasant act, provoking, inciting, or spreading false news (also refer to Mangantibe, 2016).

Through the pocket book of dealing with hate speech, The National Commission of Human Rights defined hate speech as all acts and efforts, directly or indirectly, that are based on hate toward tribe, religion, religious sect, belief, race, inter-groups, skin 
color, ethnic, gender, people with disabilities, and sexual orientation in the form of incitement toward individual or group to cause discrimination, violence, disappearance of life and/or social conflict committed by various means (Komnas HAM, 2016).

Regarding this matter, a country that carries out democratic system like Indonesia has a big challenge in managing harmony of the multicultural society. This nation should be able to manage and anticipate hate speech. This is because in democratic system, every citizen has the freedom of speech. This management aims to prevent social conflict in plural society (refer to Rongiyati, 2015). The inability of government in anticipating and dealing with hate speech could send this nation to the door of disunity and destruction.

Every year, the number of report on hate speech keeps increasing. Data shows that from 2013 to 2014, there is 53\% increase (check Simangunsong, 2016). Referring to Head of Subdirectorate IT and Cyber Crime Directorate of Special Economic Crimes Indonesian Police, Kombes Pol Himawan Bayu Aji (http://nasional.kompas.com, August 27, 2017), he mentioned that content about hate speech is the most reported crime. In 2015, the number of report concerning hate speech is 671 reports. The report is also high in 2016. From February to May 2017, Police stated that there are thousands of hate-speech crimes reported from various region in Indonesia. The number reaches $80 \%$ from all reports concerning cyber crime (https://news.detik.com, accessed on August 27 2017).

Regarding the hate speech phenomena, one step that can be taken to anticipate is by teaching and implementing language politeness. In order to be able to use polite language, according to Sibarani (2014), several strategies can be done, they are (1) using language that has most benefit to others and least benefit to oneself, (2) avoiding dirty, harsh, and taboo expressions and words, (3) using euphemism to smoothen harsh or taboo words that cannot be avoided in communicating, (4) using honorific or words that indicate respect to others, (5) using indirect speech and speech that contains optionality. Such politeness strategies can be applied in Bahasa Indonesia. According to Pranowo (2009: 4), there is a politeness structure in a language structure. Bahasa Indonesia for example, as the national language, had already been used since the beginning as language of unity. It is a language that can be projected as a communication tool that can attach diversity above the historical values of this nation's freedom fight.

\section{Language Politeness of Indonesian Society}

Not a few of research has been done to examine the politeness of language in Indonesia in various aspects of life. Several books have also been published to discuss the phenomenon of language politeness. The results show that there is language impoliteness and politeness. In the midst of a plural society there is certainly a polite and impolite language. Such phenomena will continue to occur as long as humans still use language. In real life it can be seen that the language-related politeness barely decreases. Whilst, language impoliteness is increasing in particular. According to 
Pranowo (2009: 51) it happens because of several reasons, i.e (1) Not all people understand the rules/strategies of language politeness, (2) there is a grasp of politeness strategy but not able to use it, (3) there is an adept politeness strategy but not aware upon the use of politeness strategy, (4) do not understand the rules of politeness and not proficient in polite language.

To overcome the reality of the society then the things that need to be done to improve the politeness of a multicultural society are (1) describing the rules of good language politeness, (2) continuous socialization in various institutions both formal and informal ones.

Although the Indonesian language does not yet have a certain rule of politeness by default, at least polite signs can be identified yet. Grice (1978) identifies language politeness as having to pay attention to the principle of cooperation. Complementing Grice, Leech (1983) has also proposed some rules / maxims to communicate politely. Likewise, Brown and Levinson (1987) have also proposed several strategies on language politeness. Finally, Leech (2014) proposes a politeness strategy that can be applied in the midst of multicultural society. A politeness strategy that can be done by the speaker by reducing or by weakening the negative expression to the speaker. According to the strategy Neg-Politeness includes indirectness, hedging and understatement. Meanwhile, to add to the impression of politeness, speakers can use post-politeness strategy, that is by adding or strengthening expressions that express positive values to the speakers.

The two steps above is certainly not an easy thing to do. Nevertheless, efforts to improve this country's condition should continue to be carried out, one of them is through education based on local wisdom character (see Sibarani, 2015). The government through the ministries of education and culture has taken steps to deal with the degradation of multidimensional character by applying character education in schools and has formulated eighteen (18) character values that will be taught to the younger generation of the nation for the betterment of a more peaceful and prosperous Indonesia as a nation. Character in this case is understood as the values of human behavior associated with God Almighty, individual, fellow human beings, environment, and nationality that manifested in thoughts, attitudes, feelings, utterances, deeds based on religious norms, law, manner, culture, customs (Zubaedi, 2012: 10).

In the development of Indonesian character, local wisdom becomes an important source that must be owned by the next generation of nation. Character formation implies teaching, inheriting and applying local wisdom as cultural values to young generations. Local wisdom is the value of local culture that can be utilized to regulate the life order of society wisely, the word "local" in local wisdom here is 'sectional' (Sibarani, 2015). Local wisdom that comes from cultural traditions or oral tradition is very important applied to be the source of character formation and identity especially for the younger generation of Indonesia. Local wisdom does not only deal with the meaning and functioning of cultural traditions, but further with the norms and values 
Proceedings of the $1^{\text {st }}$ Annual International Conference on Language and Literature, 18-19 April 2018, Fakultas Sastra, UISU, Medan, Indonesia.

of cultural traditions that can be applied in dealing with the problems of the nation and the country today.

\section{Conclusion}

The problems faced by the Indonesia today are so complex that they can threaten the integrity of the nation. The problems that can threaten the unity and integrity of this republic are not only derived from differences in certain political and ideological attitudes. But it is also originated and begun from language impoliteness to hate speech. Language politeness can be explored and developed from every language structure and local wisdom of the society as the user. On the other hand, hate speech can be avoided by applying language politeness and practicing the values of local wisdom. Therefore, language politeness and character education based on local wisdom are important to be applied immediately in various levels of education. Socialization and descriptions of language politeness also need to be continuously implemented in various institutions both formal and non-formal. All that is done to improve the country's condition for the future of a more peaceful nation, polite, prosperous and serene.

\section{References}

Baryadi, Praptomo. (2012). Bahasa, Kekuasaan, dan Kekerasan. Yokyakarta: University Sanata Dharma.

Brasdefer, J. Cesar Felix. (2014). "Speech Act Sequences" in Bublitz, Wolfram, eds, Handbooks of Pragmatics. Berlin/Boston: De Gruyter Mouton.

Chaer, Abdul. (2010). Kesantunan Berbahasa. Jakarta: Rineka Cipta.

Griffiths, Patrick. (2006). An Introduction to English Semantics and Pragmatics. Edinburgh: Edinburgh University Press.

Kepolisian Negara Republik Indonesia. (2015). Surat Edaran Nomor: SE/6/X/2015. Jakarta.

Komnas HAM Republik Indonesia. (2016). Buku Saku Penanganan Ujaran Kebencian. Jakarta.

Leech, Geofrey. (2014). The Pragmatics of Politeness. New York: Oxford University Press.

Leech, Geofrey. (1983). Priciples of Pragmatics. New York: Longman.

Mangantibe, Vaesy. (2016). Ujaran Kebencian Dalam Surat Edaran Kapolri Nomor: SE/6/X/2015 Tentang Penanganan Ucapan Kebencian (Hate Speech). Jurnal Lex Crimen [online], Volume 5 (1), p. 159-162. Retrieved from https://ejournal.unsrat.ac.id/index.php/lexcrimen/article/view/10614.

Muhadjir. (2016). "Perlu Dibangun Ragam Bahasa Politik yang Santun" in Riris K. Toha Sarumpaet (ed.), Krisis Budaya?. Jakarta: Yayasan Pustaka Obor Indonesia.

Pranowo. (2009). Berbahasa Secara Santun. Yogyakarta: Pustaka Pelajar.

Purnomo, Maslathif Dwi. (2017). The Power of Language (Kuasa Bahasa) Dalam Dimensi Sosial, Politik, Budaya dan Pendidikan. Yogyakarta: Naila Pustaka.

Rongiyati, Sulasi. (2015). Surat Edaran Kapolri Tentang Ujaran Kebencian: Menjaga Kebebasan Berpendapat Dan Harmonisasi Kemajemukan. Info Singkat, Vol.II, No.21. 
Proceedings of the $1^{\text {st }}$ Annual International Conference on Language and Literature, 18-19 April 2018, Fakultas Sastra, UISU, Medan, Indonesia.

Sibarani, Robert. (2004). Antropolinguistik: Antropologi Linguistik-Linguistik Antropologi. Medan: Poda.

Sibarani, Robert. (2015). Pembentukan Karakter: Langkah-langkah Berbasis Kearifan Lokal. Jakarta: Asosiasi Tradisi Lisan.

Simangunsong, Benedictus A. (2016). Ujaran Kebencian: Membangun Literasi Era Digital. Proceeding Internasional Conference of Communication, Industry and Community. Jakarta, 1 Februari 2016.

Siregar, Bahren Umar. (2011). Seluk-Beluk Fungsi Bahasa. Jakarta: Pusat Kajian Bahasa dan Budaya Universitas Katolik Indonesia Atma Jaya.

Sosiowati, I Gusti Ayu Gde. (2013). "Kesantunan Bahasa Politisi dalam Talk Show di Metro TV". (Unpublished Ph.D thesis) Universitas Udayana, Bali.

Tarigan, Henry Guntur. (1990). Pengajaran Pragmatik. Bandung: Angkasa.

Zubaedi. (2012). Desain Pendidikan Karakter: Konsepsi dan Aplikasinyaa dalam Lembaga Pendidikan. Jakarta: Kencana. 